DOI: https://doi.org/10.24127/ajpm.v10i4.4255

\title{
PENERAPAN PROBLEM BASED LEARNING BERBASIS ETNOMATEMATIKA TERHADAP BEPIKIR KREATIF MATEMATIS
}

\author{
Sofri Rizka Amalia ${ }^{1 *}$, Dian Purwaningsih ${ }^{2}$, Eka Farida Fasha ${ }^{3}$ \\ $1^{*, 2,3}$ Universitas Peradaban, Bumiayu, Indonesia \\ *Corresponding author \\ E-mail: sofri.rizkia@gmail.com ${ }^{1 *}$ \\ dian.purwaningsih24@yahoo.com $^{2)}$ \\ Efaridafasha@yahoo.co.id ${ }^{3)}$
}

Received 20 September 2021; Received in revised form 17 November 2021; Accepted 27 December 2021

\begin{abstract}
Abstrak
Tujuan penelitian ini adalah menguji penerapan model PBL berbasis etnomatematika terhadap kemampuan berpikir kreatif. Penelitian ini adalah penelitian eksperimen dengan desain The One Group Pretest-Post test. Subjek dalam penelitian ini adalah mahasiswa semester 2 program studi pendidikan matematika Universitas Peradaban Bumiayu. Pengumpulan data yang digunakan adalah tes. Teknik analisis data yang digunakan dalam penelitian ini adalah uji paired t test. Hasil penelitian ini adalah hasil uji paired sample $t$ test menunjukkan nilai $t_{\text {hitung }}<t_{\text {tabel }}$ atau $-1,853<1,729$, maka Ho di tolak yang berarti penerapan model PBL berbasis etnomatematika meningkatkan kemampuan berpikir kreatif.
\end{abstract}

Kata kunci: Berpikir kreatif matematis; etnomatematika; problem based learning.

\begin{abstract}
The purpose of this study was to examine the application of the ethnomathematical-based PBL model to the ability to think creatively. This research is an experimental study with the design of The One Group Pretest-Post test. The subjects in this study were second semester students of the mathematics education study program at the Bumiayu Civilization University. The data collection used is a test. The data analysis technique used in this study was paired t test. The results of this study are the results of the paired t-test sample test shows the value of tcount $<$ ttable or $-1,853<1,729$, then the number means that the application of the ethnomathematical-based PBL model improves creative thinking skills.
\end{abstract}

Keywords: Ethnomathematics; mathematical creative thinking; problem based learning.

This is an open access article under the Creative Commons Attribution 4.0 International License

\section{PENDAHULUAN}

Kompetensi dasar dari ilmu pengetahuan dan teknologi menerapkan dan mengembangkan berpikir ilmiah secara kritis, kreatif dan mandiri (Menteri Pendidikan Republik Indonesia, 2009). Matematika merupakan salah satu pelajaran yang merupakan kelompok ilmu pengetahuan. Oleh karena itu, pembelajaran matematika mempunyai tujuan untuk mengembangkan kemampuan berpikir secara kritis, kreatif, dan mandiri.

Kemampuan berpikir kreatif merupakan kemampuan seseorang untuk melahirkan sesuatu yang baru, baik kerupa gagasan maupun karya nyata yang relatif berbeda dengan yang telah ada sebelumnya (Noviyana, 2017). Selain itu, menurut Meika \& Sujana (2017), kemampuan berpikir kreatif merupakan cara berpikir untuk mengubah atau mengembangkan suatu permasalahan, melihat situasi atau 
permasalahan dari sisi yang berbeda, terbuka pada berbagai ide dan gagasan bahkan yang tidak umum. Dalam pembelajaran matematika diharapkan mahasiswa dapat mengembangkan gagasan kreatif yang dimiliki tentang berbagai konsep matematika.

Permasalahan di lapangan menunjukkan bahwa kemampuan berpikir kreatif mahasiswa semester IV program studi pendidikan matematika Universitas Peradaban masih kurang pada mata kuliah kapita selekta matematika I. Hal ini terjadi karena mahasiswa masih menggunakan cara atau prosedur yang biasa digunakan dalam menyelesaikan permasalahan. Mahasiswa belum bisa mencari gagasan-gagasan yang kreatif untuk menyelesaikan permasalahan. Mahasiswa menggunakan langkah yang pernah diperolehnya dan tidak mencari alternatif lainnya. Permasalahan yang sama terjadi dalam penelitian lain yaitu guru/dosen lebih dominan sehingga mahasiswa/siswa tidak dapat mengembangkan kreatifitas berpikirnya (Fahrudin (2017); (Akmalia et al. (2016); Ulfa \& Asriana (2018)). Hal ini menunjukkan bahwa kemampuan berpikir kreatif masih belum maksimal berkembang.

Berbagai upaya dapat dilakukan untuk mengembangkan kemampuan berpikir kreatif. Hasil penelitian yang relivan menunjukkan bahwa model PBL efektif untuk meningkatkan kemampuan berpikir kreatif (Ulfa \& Asriana (2018); Muntaha \& Hartono (2013); Novellia (2018); Fahrudin (2017)). Berdasarkan beberapa hasil penelitian tersebut, maka dapat perlu dilakukan penerapan model PBL untuk mengembangkan kemampuan berpikir kreatif.

Pembelajaran dengan model PBL dilakukan dengan memberikan masalah yang berkaitan dengan kehidupan nyata pada awal pembelajaran dan masalah yang diberikan bersifat terbuka sehingga siswa dapat menggali dan menemukan banyak strategi (Siviani et al., 2018). Sedangkan menurut Utomo et al. (2014), model PBL merupakan pembelajaran yang menyajikan masalah pada awal pembelajaran yang menuntut aktivitas siswa. Berdasarkan beberapa ahli dapat disimpulkan bahwa model PBL merupakan model pembelajaran yang memberikan masalah saat awal pembelajaran yang membuat siswa aktif menggali informasi sehingga dapat menyelesaikan permasalahan.

Keunggulan PBL yaitu 1) siswa memahami isi pelajaran dengan mudah, 2) siswa dapat menemukan informasi dan pengetahuan baru karena guru memberikan permasalahan yang harus diselesaikan sehingga kemampuan siswa berkembang, 3) siswa lebih aktif, 4) siswa dilatih untuk menyelesaikan permasalahan kehidupan nyata, 5) siswa dapat mengembangkan pengetahuan barunya dan saling bekerja sama serta bertanggung jawab dalam kelompok, 6) siswa dapat melakukan evaluasi diri, 7) pembelajaran terasa lebih menyenangkan, 8) siswa dapat mengaplikasikan pengetahuan yang mereka miliki pada kehidupan nyata(Firdaus et al., 2021). Dengan keunggulan tersebut siswa dapat berpikir kreatif untuk menyelesaikan permasalahan kehidupan sehari hari. Sehingga kemampuan berpikir kreatifnya dapat berkembang dalam menyelesaikan permasalahan.

Dalam penerapan model PBL, permasalahan yang di berikan merupakan permasalahan yang bermuatan etnomatematika. Menurut Amalia \& Isnani (2019), etnomatematika merupakan aktivitas matematika yang berkaitan dengan budaya. Masalah yang diajukan adalah 
masalah yang berkaitan dengan aktivitas matematika. Model PBL bermuatan etnomatematika membuat mahasiswa dapat mengembangkan dan menerapkan pengetahuan yang dimilikinya lebih bermakna (Amalia \& Widodo, 2018). Hal ini sejalan Abdullah et al (2015) pembelajaran lebih mudah dipahami apabila dalam penerapan model PBL, masalah yang di gunakan adalah masalah yang ada dilingkungan sekitar khususnya budaya lokal (etnomatematika) dengan harapan pembelajaran akan lebih bermakna.

Kebaruan penelitian ini adalah dengan menerapkan model PBL berbasis etnomatematika untuk meningkatkan kemampuan berpikir kreatif matematis. Pembelajaran dengan model PBL akan membuat mahasiswa terbiasa memecahkan permasalahan sehingga dapat mengembangkan kemampuan berpikir kreatif. Permasalahan yang diberikan berkaitan dengan budaya matematika (etnomatematika). Hal ini dapat memudahkan mahasiswa dalam menyelesaikan masalah karena berkaitan dengan budaya yang ada di masyarakat.

Berdasarkan latar belakang diatas, tujuan penelitian ini adalah menguji penerapan model PBL berbasis etnomatematika terhadap kemampuan berpikir kreatif.

\section{METODE PENELITIAN}

Penelitian ini adalah penelitian eksperimen dengan desain The One Group Pretest-Post test (Ratminingsih, 2010). Prosedur penelitian ini adalah (1) menentukan fokus penelitian: fokus yang diambil adalah penerapan model PBL berbasis etnomatematika terhadap kemampuan berpikir kreatif, (2) studi pendahuluan: melakukan investigasi kemampuan yang dimiliki mahasiswa dan melakukan wawancara terhadap dosen, (3) merumuskan masalah sesuai dengan pemasalahan yang diperoleh, (4) menyusun kerangka teori, (5) menyusun kerangka pikir penelitian, (6) hipotesis, (7) memilih metode penelitian, (8) menentukan variabel dan indikator, (9) menyusun instrumen, (10)m mengumpulkan data, (11) analisis data, (12) Menarik kesimpulan.

Subjek dalam penelitian ini adalah mahasiswa semester 2 program studi pendidikan matematika Universitas Peradaban Bumiayu yang berjumlah 21 mahasiswa. Model PBL berbasis etnomatematika diterapkan dalam pembelajaran pada mata kuliah kapita selekta matematika I.

Pengumpulan data yang digunakan adalah tes. Tes dilakukan pada awal sebelum pembelajaran dan setelah seluruh pembelajaran selesai. Tes digunakan untuk mengetahui kemampuan berpikir kreatif mahasiswa. Tes terdiri dari 8 soal uraian yang dibuat sesuai dengan indikator kemampuan berpikir kreatif.

Tes di uji validitas terlebih dahulu sebelum dipergunakan dengan menggunakan uji validitas product moment, uji reliabilitas Alfa Cronbach, tingkat kesukaran dan daya pembeda soal uraian (Yusup, 2018). Uji prasyat sebelum analisis data adalah uji normalitas. Teknik analisis data yang digunakan dalam penelitian ini adalah uji paired t test, dan uji n gain.

\section{HASIL DAN PEMBAHASAN}

Penelitian ini dilakukan dengan menerapkan model PBL berbasis etnomatematika. Langkah langkah pembelajaran disajikan pada Tabel 1 . 
DOI: https://doi.org/10.24127/ajpm.v10i4.4255

Tabel 1. Langkah-langkah pembelajaran PBL berbasis etnomatematika

\begin{tabular}{|c|c|}
\hline Fase & Kegiatan Pembelajaran \\
\hline Fase 1: & a. Membahas tujuan pembelajaran \\
\hline Orientasi masalah & $\begin{array}{l}\text { b. Mendeskripsikan hal yang akan dilakukan dalam } \\
\text { mengatasi masalah berbasis etnomatematika }\end{array}$ \\
\hline $\begin{array}{l}\text { Fase } 2 \text { : } \\
\text { Mengorganisasikan mahasiswa } \\
\text { agar melakukan penelitian }\end{array}$ & $\begin{array}{l}\text { Membantu mahasiswa mendefinisikan dan } \\
\text { mongorganisasikan tugas-tugas belajar berkaitan } \\
\text { dengan masalah berbasis etnomatematika }\end{array}$ \\
\hline Fase $3:$ & Mendorong mahasiswa untuk memperoleh \\
\hline $\begin{array}{l}\text { Membantu mahasiswa } \\
\text { melakukan investigasi secara } \\
\text { mandiri dan kelompok }\end{array}$ & $\begin{array}{l}\text { informasi yang tepat mengenai permasalahan } \\
\text { dilingkungan sekitas berbasis etnomatematika, } \\
\text { melaksanakan eksperimen, serta mencari } \\
\text { penjelasan dan solusi. }\end{array}$ \\
\hline $\begin{array}{l}\text { Fase } 4 \text { : mengembangkan dan } \\
\text { mempresentasikan hasil kerja }\end{array}$ & $\begin{array}{l}\text { Membantu mahasiswa merencanakan dan } \\
\text { menyiapkan hasil karya }\end{array}$ \\
\hline & $\begin{array}{l}\text { Membantu mahasiswa untuk menyampaikan } \\
\text { pendapat }\end{array}$ \\
\hline $\begin{array}{l}\text { Fase } 5 \text { : } \\
\text { Menganalisis dan mengevaluasi }\end{array}$ & $\begin{array}{l}\text { Membantu mahasiswa melakukan refleksi dan } \\
\text { evaluasi tehadap hasil kerja. }\end{array}$ \\
\hline
\end{tabular}

(Abdurrozak \& Jayadinata, 2016)

Sebelum perkuliahan dimulai dilakukan pretest dan setelah dilakukan perkuliahan dilakukan postest. Pretest dan posttest digunakan untuk memperoleh data tentang kemampuan berpikir kreatif matematis.

Analisis data dalam penelitian ini adalah uji Paired $t$ test. Uji prasyarat dilakukan sebelum analisis data yaitu uji normalitas. Uji ini bertujuan untuk mengetahui apakah kelas yang memiliki distribusi normal. Adapun hipotesisnya sebagai berikut:

$H_{0} \quad$ : Data berdistribusi normal

$H_{1}$ : Data tidak berdistribusi normal

Hasil output uji normalitas dengan SPSS disajikan pada Tabel .

Tabel 2. Hasil Tests of Normality

\begin{tabular}{lrrr}
\hline & \multicolumn{3}{c}{ Shapiro-Wilk } \\
\cline { 2 - 4 } & Statistic & df & \multicolumn{1}{c}{ Sig. } \\
\hline Sebelum & 0,938 & 21 & 0,200 \\
Sesudah & 0,938 & 21 & 0,184 \\
\hline
\end{tabular}

Hasil uji normalitas menunjukkan nilai signifikan Shapiro Wilk kelas sebelum diajar dengan model PBL berbasis etnomatematika adalah 0,200 > 0,05 . Terlihat $0,200>0,05$, maka Ho diterima artinya data sebelum pembelajaran berdistribusi normal. Sedangkan signifikan kelas sesudah diajar dengan model PBL berbasis etnomatematika sebesar 0,184 . Terlihat bahwa 0,184>0,05, maka maka Ho diterima artinya data sesudah pembelajaran berdistribusi normal. Uji prasyarat sudah terpenuhi, selanjutnya dilakukan uji paired sample t test.

Berikut hasil analisis data. Hipotesis yang digunakan dalam penelitian ini adalah sebagai berikut.

$H_{0}: \mu_{1} \leq \mu_{2} \quad$ (kemampuan berpikir kreatif matematis setelah penerapan model PBL berbasis etnomatematika kurang dari atau sama dengan kemampuan berpikir kreatif matematis sebelum penerapan model PBL berbasis etnomatematika) 
DOI: https://doi.org/10.24127/ajpm.v10i4.4255

$H_{1}: \mu_{1}>\mu_{2} \quad$ (kemampuan berpikir kreatif matematis setelah penerapan model PBL berbasis etnomatematika lebih dari kemampuan berpikir kreatif matematis sebelum penerapan model PBL berbasis etnomatematika.

Hasil uji paired sample $t$ test disajikan pada Tabel 3.

Tabel 3. Hasil SPSS uji paired samples t-test

\begin{tabular}{|c|c|c|c|c|c|c|c|}
\hline & \multicolumn{3}{|c|}{ Paired Differences } & \multirow[b]{2}{*}{$t$} & \multirow[b]{2}{*}{$d f$} & \multirow[b]{2}{*}{$\begin{array}{l}\text { Sig. }(2- \\
\text { tailed })\end{array}$} \\
\hline & & Mean & $\begin{array}{c}\text { Std. } \\
\text { Deviation }\end{array}$ & $\begin{array}{c}\text { Std. Error } \\
\text { Mean }\end{array}$ & & & \\
\hline Pair 1 & Posttest - Pretest & 7,810 & 15,449 & 3,871 & 2.317 & 20 &, 031 \\
\hline
\end{tabular}

Berdasarkan hasil uji paired t test terlihat bahwa $t=2,317$ dengan $d f($ derajat kebebasan $)=19$. Nilai $t_{\text {tabel }}=t_{(19,0,05)}=1,729$. Jadi, dapat disimpulkan bahwa nilai $t_{\text {hitung }}>$ $t_{\text {tabel }}$ atau 2,317 $>1,729$, maka Ho di tolak yang berarti kemampuan berpikir kreatif matematis setelah penerapan model PBL berbasis etnomatematika lebih dari kemampuan berpikir kreatif matematis sebelum penerapan model PBL berbasis etnomatematika.

Selanjutnya dilakukan uji gain untuk melihat seberapa besar peningkatan kemampuan berpikir kreatif secara mendalam. Hasil uji $n$ gain disajikan pada Tabel 4.

Tabel 4 Kategori n-gain

\begin{tabular}{c|c}
\hline Kategori & $\begin{array}{c}\text { Jumlah } \\
\text { mahasiswa }\end{array}$ \\
\hline Tinggi $(g \geq 0,70)$ & 3 \\
Sedang $(3 \leq g<0,70)$ & 9 \\
Rendah $(g<0,30)$ & 9 \\
\hline
\end{tabular}

Dari hasil uji $\mathrm{n}$ gain terlihat bahwa banyak siswa yang mengalami peningkatan kategori tinggi sebanyak 3 orang, sedang dan rendah sebanyak 9 orang. Hal tersebut menunjukkan bahwa peningkatan kemampuan berpikir kreatif terjadi saat pembelajaran.

Hasil uji tersebut sesuai dengan pembelajaran di lapangan. Dalam pembelajaran model PBL berbasis etnomatematika diterapkan dengan beberapa langkah pembelajaran yaitu orientasi masalah, mengorganisasikan mahasiswa untuk belajar, membimbing pengalaman mahasiswa secara individu maupun kelompok, menyajikan hasil pekerjaan mahasiswa, dan melakukan evaluasi proses belajar mahasiswa. Masalah yang diberikan pada tahap orientasi adalah masalah yang berkaitan dengan budaya matematika (etnomatematika), selain itu mahasiswa diberi kesempatan menemukan masalah sendiri di lingkungannya dan menyelesaikan masalah tersebut. Hal ini dapat membuat mahasiswa tidak asing dengan masalah yang diberikan dan yang di temukan sehingga memudahkan mahasiswa untuk menyelesaikan masalah dengan berbagai cara. Mahasiswa dapat secara langsung menemukan masalah sendiri yang ada dilingkungannya dan mengetahui penyelesaian yang tepat. Hal tersebut dapat mengembangkan kemampuan berpikir kreatif.

Kekurangan yang terjadi saat pembelajaran di awal adalah terdapat beberapa mahasiswa yang masih belum berani untuk menyajikan hasil karya di depan kelas walaupun secara online. Kekurangan ini terjadi karena mata kuliah kapita selekta matematika I berada di semester 2 sehingga masih 
ada beberapa mahasiswa yang masih malu. Hal ini dapat diatasi dengan pemberian poin atau nilai kepada mahasiswa yang berani berpendapat dan menyajikan hasil.

Hasil tersebut diperkuat oleh beberapa peneliti terdahulu. Berdasarkan hasil penelitian Cahyono (2017), ketuntasan kemampuan berpikir kreatif mencapai $84,62 \%$. Selain itu, menurut Abdurrozak \& Jayadinata (2016), terdapat peningkatan kemampuan berpikir kreatif siswa dengan menggunakan model PBL, dan kemampuan berpikir kreatif siswa dengan menggunakan model PBL lebih baik daripada menggunakan model konvensional. Penelitian lain menyebutkan bahwa penerapan model Problem Based Learning (PBL) terbukti dapat meningkatkan kemampuan berpikir kreatif dan hasil belajar siswa (Novellia, 2018). Model pembelajaran Problem Based Learning efektif terhadap kemampuan berpikir kreatif mahasiswa (Fahrudin, 2017). Hal ini diperkuat lagi oleh Dewi \& Masrukan (2018) yang menyebutkan bahwa peningkatan kemampuan berpikir kreatif mahasiswa yang signifikan dalam pembelajaran open ended atau masalah.

Implikasi penelitian ini adalah penerapan model PBL dapat meningkatkan kemampuan berpikir kreatif. Model PBL dipadukan dengan etnomatematika dapat mengembangkan kemampuan berpikir kreatif mahasiswa dengan masalah-masalah yang ada di lingungan sekitar.

\section{KESIMPULAN DAN SARAN}

Berdasarkan hasil penelitian, dapat disimpulkan bahwa penerapan model PBL berbasis etnomatematika mampu meningkatkan kemampuan berpikir kreatif.
Saran dalam penelitian ini adalah model PBL dapat dipadukan dengan pendekatan lain. Selain itu, penerapan model PBL dapat ditinjau dari berbagai kemampuan matematis lainnya.

\section{DAFTAR PUSTAKA}

Abdullah, D. I., Mastur, Z., \& Sutarto, H. (2015). Keefektifan Model Pembelajaran Problem Based Learning Bernuansa Etnomatematika Terhadap Kemampuan Pemecahan Masalah Siswa Kelas Viii. Unnes Journal of Mathematics Education., 4(3). https://doi.org/10.15294/ujme.v4i 3.9056

Abdurrozak, R., \& Jayadinata, A. K. (2016). Pengaruh Model Problem Based Learning Terhadap Kemampuan Berpikir Kreatif Siswa. Jurnal Pena Ilmiah, 1(1), 871-880.

https://doi.org/10.23819/pi.v1i1.3 580

Akmalia, N. N., Pujiastuti, H., \& Setiani, Y. (2016). Identifikasi Tahap Berpikir Kreatif Matematis Melalui Penerapan Model Problem Based Learning. Jurnal Pengabdian Dan Pemberdayaan Masyarakat, 9(2), 183-193.

Amalia, S. R., \& Isnani. (2019). Representasi Matematis dalam Pembelajaran dengan Model Problem-Based Learning Berbasis Etnomatematika Ditinjau dari Tipe Kepribadian. 5(2), 190-205. https://doi.org/10.29408/jel.v5i2.1 325

Amalia, S. R., \& Widodo, A. N. ami. (2018). Analisis Kemampuan Pemecahan Masalah Mahasiswa Melalui Model Pbl Berbasis Etnomatematika Ditinjau dari Kepribadian Topologi 
DOI: https://doi.org/10.24127/ajpm.v10i4.4255

Hippocrates , Galenus Tipe Cholearis dan Phlegmantis. Aksioma, 9(1), 1-10.

Cahyono, A. E. Y. (2017). Pengembangan Perangkat Pembelajaran Problem-Based Learning Berorientasi pada Kemampuan Berpikir Kreatif dan Inisiatif Siswa. PYTHAGORAS: Jurnal Pendidikan Matematika, 12(1), 1-11.

Dewi, N. R., \& Masrukan. (2018). Peningkatan Kemampuan Berpikir Kreatif Mahasiswa Program Magister. Prisma, Prosicing Seminar Nasional Matematika, 1, 539-546.

Elizabeth, A., \& Sigahitong, M. M. (2018). Pengaruh Model Problem Based Learning Terhadap Kemampuan Berpikir Kreatif Peserta Didik SMA. Prisma Sains: Jurnal Pengkajian Ilmu Dan Pembelajaran Matematika Dan IPA IKIP Mataram, 6(2), 66. https://doi.org/10.33394/jps.v6i2.1044

Fahrudin, F. A. (2017). Efektivitas Problem Based Learning Terhadap Kemampuan Berpikir Kreatif Mahasiswa Program Studi Tadris Matematika UIN Mataram. JTAM | Jurnal Teori Dan Aplikasi Matematika, 1(1), 41. https://doi.org/10.31764/jtam.v1i1 .185

Firdaus, A., Asikin, M., Waluya, B., \& Zaenuri, Z. (2021). Problem Based Learning (PBL) Untuk Meningkatkan Kemampuan Matematika Siswa. QALAMUNA: Jurnal Pendidikan, Sosial, Dan Agama, 13(2), 187-200. https://doi.org/10.37680/qalamuna .v13i2.871

Meika, I., \& Sujana, A. (2017). Kemampuan Berpikir Kreatif Dan
Pemecahan Masalah Matematis Siswa Sma. Jurnal Penelitian Dan Pembelajaran Matematika, 10(2), 8-13.

https://doi.org/10.30870/jppm.v10 i2.2025

Muntaha, A., \& Hartono. (2013). Model Problem Based Learning Untuk Meningkatkan. Journal of Primary Educational, 2(2).

Novellia, M. (2018). Penerapan Model Pembelajaran Problem Based Learning (Pbl) Untuk Peningkatan Kemampuan Berpikir Kreatif Dan Hasil Belajar Siswa Dalam Pembelajaran Tematik. Journal for Lesson and Learning Studies, 1(2), 149-156. https://doi.org/10.23887/jlls.v1i2. 14760

Noviyana, H. (2017). Pengaruh Model Project Based Learning Terhadap Kemampuan Berpikir Kreatif Matematika Siswa. JURNAL EDuMath, $3(2)$. https://doi.org/10.26638/je.455.20 64

PERATURAN MENTERI PENDIDIKAN NASIONAL REPUBLIK INDONESIA, 1 (2009).

Ratminingsih, N. made. (2010). Experimental Research in Second Language. PRASI, 6(11), 30-40.

Siviani, R., Zubainur, C. M., \& Subianto, M. (2018). Kemampuan Berpikir Kreatif Siswa SMP melalui Model Problem Based Learning. Jurnal Didaktik Matematika, 5(1), 27-39. https://doi.org/10.24815/jdm.v5i1. 10125

Ulfa, F. M., \& Asriana, M. (2018). Keefektifan Model PBL dengan Pendekatan Open-ended pada Pencapaian Kemampuan Berpikir Kreatif Matematis dan Disposisi 
DOI: https://doi.org/10.24127/ajpm.v10i4.4255

Matematis Siswa. Prisma, Prosicing Seminar Nasional Matematika, 1, 289-298.

Utomo, T., Wahyuni, D., Hariyadi, S., Studi, P., Biologi, P., Keguruan, F., \& Unej, U. J. (2014). Pengaruh Model Pembelajaran Berbasis Masalah ( Problem Based Learning ) Terhadap Pemahaman Konsep dan Kemampuan Berpikir Kreatif Siswa ( Siswa Kelas VIII Semester Gasal SMPN 1 Sumbermalang Kabupaten Situbondo Tahun Ajaran 2012 / 2013 ) ( The Effect of Pro. Jurnal Edukasi UNEJ, 7, 5-9.

Yusup, F. (2018). Uji Validitas dan Reliabilitas Instrumen Penelitian Kuantitatif. Jurnal Tarbiyah: Jurnal Ilmiah Kependidikan, 7(1), 17-23.

https://doi.org/10.18592/tarbiyah. v7i1.2100 